DOI: $10.15193 /$ zntj/2017/110/176

\author{
MAŁGORZATA PIECYK, ELWIRA WOROBIEJ, JUSTYNA TUROS, \\ EWA OSTROWSKA-LIGĘZA
}

\title{
WŁAŚCIWOŚCI I STRAWNOŚĆ IN VITRO SKROBI GRYCZANEJ W PORÓWNANIU ZE SKROBIĄ PSZENNĄ
}

\author{
Streszczenie
}

Produkty z udziałem mąki gryczanej charakteryzują się dobrą wartością odżywczą i obecnością składników o działaniu prozdrowotnym, w tym niskim indeksem glikemicznym. Cechy te mogą być przydatne w projektowaniu nowych produktów z udziałem ziarniaków gryki. Celem pracy było porównanie wybranych właściwości wyizolowanej skrobi z gryki z właściwościami mąki gryczanej oraz skrobi pszennej.

Wykazano, że ze względu na ponad 10-krotnie mniejszą wielkość ziarenek skrobi gryczanej w stosunku do skrobi pszennej ich właściwości znacznie się różnią, pomimo że obie mają ten sam typ struktury polimorficznej i podobną zawartość amylozy. Skrobia gryczana charakteryzowała się większą temperaturą i entalpią przemiany kleikowania niż skrobia pszenna. W przypadku mąki gryczanej obserwowano jeszcze większe wartości temperatury przemiany kleikowania oraz niskie wartości siły pęcznienia i zdolności rozpuszczania amylozy, co wynika prawdopodobnie z obecności białek na powierzchni ziarenek skrobi. Te właściwości wpłynęły na podatność skrobi na trawienie. Skrobia w mące gryczanej (surowej) charakteryzowała się dużym udziałem frakcji opornej (RS), ale po wyizolowaniu skrobi z mąki udział RS był znikomy - mniejszy niż w skrobi pszennej. Po gotowaniu udział skrobi szybko trawionej w mące i w wyizolowanej skrobi był na zbliżonym poziomie. Po skleikowaniu udział RS był większy w skrobi gryczanej niż w pszennej, co wskazuje na większą podatność tej skrobi na retrogradację.

Słowa kluczowe: mąka gryczana, skrobia gryczana i pszenna, skrobia oporna (RS), pęcznienie skrobi, rozpuszczalność amylozy

\section{Wprowadzenie}

Obserwowane zainteresowanie ziarniakami gryki i produktami z nich otrzymanymi wynika z ich dobrej wartości odżywczej oraz obecności substancji o właściwo-

Dr hab. M. Piecyk, dr inż. E. Worobiej, mgr inż. J. Turos, Katedra Biotechnologii, Mikrobiologii i Oceny Żywności, dr hab. E. Ostrowska-Ligęza, Katedra Chemii, Wydz. Nauk o Żywności, Szkoła Główna Gospodarstwa Wiejskiego w Warszawie, ul. Nowoursynowska 159 C, 02-776 Warszawa.

Kontakt:malgorzata_piecyk@sggw.pl 
ściach prozdrowotnych. Główne składniki ziarniaków gryki, tj. sacharydy i białka charakteryzują się korzystniejszymi właściwościami w porównaniu ze zbożami, a wśród związków bioaktywnych czy balastowych wymienić można błonnik pokarmowy [8, 24]. Podkreślenia wymagają również związki o właściwościach przeciwutleniających głównie związki fenolowe, zwłaszcza flawonoidy, takie jak rutyna i katechiny [25] oraz lignany działające podobnie do fitoestrogenów [26], a także inne związki, jak sterole [9].

Ze względu na cenny skład ziarniaków gryki rozszerzono ofertę produktów z ich udziałem, zwłaszcza że mogą być wykorzystywane w diecie bezglutenowej. Obok tradycyjnie spożywanych produktów, jak kasza nieprażona oraz prażona, pojawiły się na rynku takie produkty, jak: mąka, płatki gryczane, kasza gryczana instant, kasza błyskawiczna czy kawa. Coraz częściej gryka jest również składnikiem złożonych produktów, jak makarony czy chleb.

Dominującym składnikiem sacharydowym decydującym o właściwościach technologicznych gryki jest skrobia, której zawartość w ziarniaku wynosi $59 \div 77 \%$ w suchej masie [23, 24], a w mące nawet do $81 \%$ [10]. O właściwościach technologicznych skrobi decyduje przede wszystkim stosunek jej głównych komponentów, tj. amylozy i amylopektyny, jej struktura polimorficzna, wielkość ziarenek oraz obecność substancji towarzyszących. Jedną z cech przypisywanych produktom z ziarniaków gryki jest to, że skrobia w niej zawarta ulega wolniejszej hydrolizie niż skrobia pszenna, powodując obniżenie indeksu glikemicznego produktów z udziałem mąki gryczanej [14]. Produkty te zawierają również większą ilość skrobi opornej niż analogiczne produkty zawierające tylko mąkę pszenną [20,21]. Interesujące jest, czy te właściwości skrobi gryczanej są wynikiem jej struktury czy raczej wynikają z obecności innych składników zawartych $\mathrm{w}$ mące. Taka wiedza może być przydatna $\mathrm{w}$ projektowaniu nowych produktów z udziałem komponentów otrzymanych z gryki.

Celem pracy było określenie wybranych właściwości skrobi gryczanej wyodrębnionej z mąki w porównaniu ze skrobią pszenną oraz z właściwościami skrobi zawartej w mące gryczanej.

\section{Material i metody badań}

Materiał doświadczalny stanowiły całe ziarniaki gryki (Fagopyrum sagittum), które zmielono, przesiano przez sito $(0,250 \mathrm{~mm})$ i otrzymano mąkę. Do izolacji skrobi zastosowano metodę na mokro, w której prowadzono przez 12 h ekstrakcję składników rozpuszczalnych po zmieszaniu mąki z wodą w stosunku $1: 10$, a następnie po przelaniu zawiesiny przez sito i odwirowaniu ekstrahowano ponownie $\mathrm{NaOH}$ o stężeniu $0,02 \mathrm{~mol} / \mathrm{dm}^{3}$. Otrzymany osad mieszano trzykrotnie z wodą za każdym razem odwirowując zawiesinę, po czym suszono w temp. $45^{\circ} \mathrm{C}$, mielono i przesiewano przez sito 
$(0,090 \mathrm{~mm})$. Materiałem porównawczym była handlowa skrobia pszenna firmy Roquette (Francja) (PS).

Do badania morfologii ziarenek skrobi gryczanej i skrobi pszennej stosowano obserwacje pod mikroskopem skaningowym (Hitachi S-4200, Japonia) przy powiększeniu 3000x, stosując napięcie przyspieszające $10 \mathrm{kV}$. W celu uniknięcia uszkodzeń przez wiązkę elektronów po naklejeniu skrobi na metalowe krążki napylano ją złotem w napylarce Jeol, typ JFC-1300. Badania podstawowego składu chemicznego mąki i skrobi obejmowały oznaczenia metodami standardowymi zawartości wody, popiołu i białka [32]. Zawartość amylozy w skrobi oznaczano metodą spektrofotometryczną Williamsa i wsp. [30].

Badanie struktury krystalicznej skrobi gryczanej i pszennej prowadzono metodą dyfrakcji promieni Roentgena (X-ray) w aparacie D8 Discover (Bruker Co., USA). Warunki pomiaru były następujące: lampa rentgenowska $\mathrm{Cu} \mathrm{K} \alpha$ (filtr $\mathrm{Ni}$ ), napięcie $40 \mathrm{kV}$, natężenie prądu $-40 \mathrm{~mA}$, skanowanie przy kącie odbłysku $-2 \theta$ w zakresie $2 \div$ $30^{\circ} \mathrm{z}$ prędkością $1,0 \% \mathrm{~min}$. W celu wyeliminowania wahań krystaliczności względnej preparatów wywołanej różnicami w ich wilgotności badane próbki skrobi kondycjonowano w atmosferze o wilgotności względnej $92 \% \mathrm{w}$ ciągu $48 \mathrm{~h}$.

Analizy kleikowania skrobi prowadzono w skaningowym kalorymetrze różnicowym (DSC, TA Instruments Q 200) według Piecyk i wsp. [17]. Z termogramów kleikowania skrobi wyznaczano temperatury: początku przemiany fazowej $\left(\mathrm{T}_{0},{ }^{\circ} \mathrm{C}\right)$, maksimum endotermy $\left(\mathrm{T}_{\mathrm{p}},{ }^{\circ} \mathrm{C}\right) \mathrm{i}$ końcową przemiany $\left(\mathrm{T}_{\mathrm{k}},{ }^{\circ} \mathrm{C}\right)$ oraz entalpię przemiany $(\Delta \mathrm{H}$, $\mathrm{J} / \mathrm{g}$ s.m.). Ponadto obliczano zakres temperatur przemiany $\left(\mathrm{T}_{\mathrm{k}}-\mathrm{T}_{\mathrm{o}}\right)$ oraz indeks wzrostu piku PHI (ang. peak height index) jako stosunek $\Delta \mathrm{H} / \mathrm{T}_{\mathrm{p}}-\mathrm{T}_{\mathrm{o}}[11]$.

Badania pęcznienia skrobi i zdolności rozpuszczania amylozy prowadzono w temp. 55, 65,75 i $85^{\circ} \mathrm{C}$ metodą Leacha i wsp. [12] w modyfikacji Piecyk i wsp. [17].

Strawność in vitro skrobi w próbkach natywnych i po skleikowaniu skrobi oznaczano metodą Englysta i wsp. [6] w modyfikacji Chunga i wsp. [4]. W celu skleikowania skrobi przygotowane jej 5-procentowe wodne zawiesiny ogrzewano $\left(\mathrm{t}=95{ }^{\circ} \mathrm{C}\right.$, $30 \mathrm{~min}$ ), a następnie chłodzono do temp. $37^{\circ} \mathrm{C}$, po czym dodawano bufor octanowy $\left(0,5 \mathrm{~mol} / \mathrm{dm}^{3} ; \mathrm{pH} 5,2\right)$ i mieszaninę enzymów. Próbki natywne i skleikowane trawiono mieszaniną enzymów, pobierano po 20 i 120 min tego procesu $100 \mu 1$ mieszaniny, w której oznaczano ilość uwolnionej glukozy testem enzymatycznym (K-GLUC, Megazyme). Do opisu strawności skrobi wyznaczano ilość skrobi szybko trawionej (RDS) zhydrolizowanej po $20 \mathrm{~min}$, a wolno trawionej (SDS) między 20. a 120. min hydrolizy. Ilość skrobi opornej (RS) stanowiła różnicę między skrobią całkowitą (TS) oznaczoną testem enzymatycznym (K-TSTA, Megazyme) a skrobią strawioną po 120 min hydrolizy.

Otrzymane wyniki z trzech powtórzeń przedstawiono jako wartości średnie i przeanalizowano przy użyciu jednoczynnikowej analizy wariancji. Istotność różnic 
między wartościami średnimi weryfikowano testem Duncana przy poziomie istotności $\mathrm{p}=0,05$. Obliczenia wykonano $\mathrm{w}$ programie Statistica v. 10.0.

\section{Wyniki i dyskusja}

W badaniach składu chemicznego mąki gryczanej (tab. 1) wykazano, że nie odbiegał on od danych literaturowych. Według tych danych zawartość białka i skrobi mieści się w zakresach odpowiednio: $6,8 \div 14,0 \%$ i $65,6 \div 80,7 \%[10,19]$, a popiołu - w zakresie $1,33 \div 2,60 \%$ [19].

Tabela 1. Skład chemiczny mąki gryczanej

Table 1. Chemical composition of buckwheat flour

\begin{tabular}{|c|c|c|c||}
\hline $\begin{array}{c}\text { Wilgotność } \\
\text { Moisture [\%] }\end{array}$ & $\begin{array}{c}\text { Zawartość popiołu } \\
\text { Content of ash } \\
{[\% \text { s.m. / d.m.] }}\end{array}$ & $\begin{array}{c}\text { Zawartość białka } \\
\text { Content of protein } \\
{[\% \text { s.m. / d.m.] }}\end{array}$ & $\begin{array}{c}\text { Zawartość skrobi } \\
\text { Content of starch } \\
{[\% \text { s.m. / d.m. }]}\end{array}$ \\
\hline $8,3 \pm 0,3$ & $1,40 \pm 0,03$ & $9,8 \pm 0,3$ & $75,2 \pm 0,5$ \\
\hline
\end{tabular}

Tabela 2. Skład chemiczny skrobi wyizolowanej z gryki i handlowej skrobi pszennej

Table 2. Chemical composition of starch isolated from buckwheat and of commercial wheat starch

\begin{tabular}{||c|c|c|c|c||}
\hline $\begin{array}{c}\text { Próbka } \\
\text { Sample }\end{array}$ & $\begin{array}{c}\text { Wilgotność } \\
\text { Moisture } \\
{[\%]}\end{array}$ & $\begin{array}{c}\text { Zawartość popiołu } \\
\text { Content of ash } \\
{[\% \text { s.m. / d.m. }]}\end{array}$ & $\begin{array}{c}\text { Zawartość białka } \\
\text { Content of protein } \\
{[\% \text { s.m. / d.m. }]}\end{array}$ & $\begin{array}{c}\text { Zawartość amylozy } \\
\text { Content of amylose } \\
{[\% \text { s.m / d.m. }]}\end{array}$ \\
\hline $\begin{array}{c}\text { Skrobia gryczana } \\
\text { Buckwheat starch }\end{array}$ & $11,1^{\mathrm{a}} \pm 0,2$ & $0,18 \pm 0,02$ & $0,48^{\mathrm{b}} \pm 0,02$ & $21,7^{\mathrm{a}} \pm 0,2$ \\
\hline $\begin{array}{c}\text { Skrobia pszenna } \\
\text { Wheat starch }\end{array}$ & $12,8^{\mathrm{b}} \pm 0,1$ & $<0,40^{*}$ & $0,24^{\mathrm{a}} \pm 0,02$ & $23,7^{\mathrm{b}} \pm 0,1$ \\
\hline
\end{tabular}

Objaśnienia / Explanatory notes:

* - specyfikacja producenta / producer's specification.

W tabeli przedstawiono wartości średnie \pm odchylenia standardowe / Table shows mean values \pm standard deviations. Wartości w kolumnach oznaczone różnymi literami są statystycznie istotnie różne przy p < 0,05 / Values in columns and denoted by different letters are statistically significantly different at $\mathrm{p}<0.05$.

Wyizolowana skrobia charakteryzowała się zawartością białka na poziomie $0,48 \%$ (tab. 2). Jest to wartość zbliżona do danych literaturowych $0,3 \div 0,5 \%$ [11, 14], chociaż podawane są również większe wartości, np. 1,15 \% [3]. Tak duże różnice mogą być wynikiem nie tylko różnych warunków uprawy czy odmiany gryki, ale są uzależnione również od metody izolacji skrobi, która w przypadku skrobi o małych ziarenkach (fot. 1) jest trudna. 
Oznaczona zawartość amylozy w skrobi gryczanej, wynosząca 21,7 \%, mieści się w zakresie podawanym w literaturze, tj. $17,1 \div 29,1 \%[1,19]$ i jest mniejsza od oznaczonej ilości w skrobi pszennej, tj. 23,7\% (tab. 2).

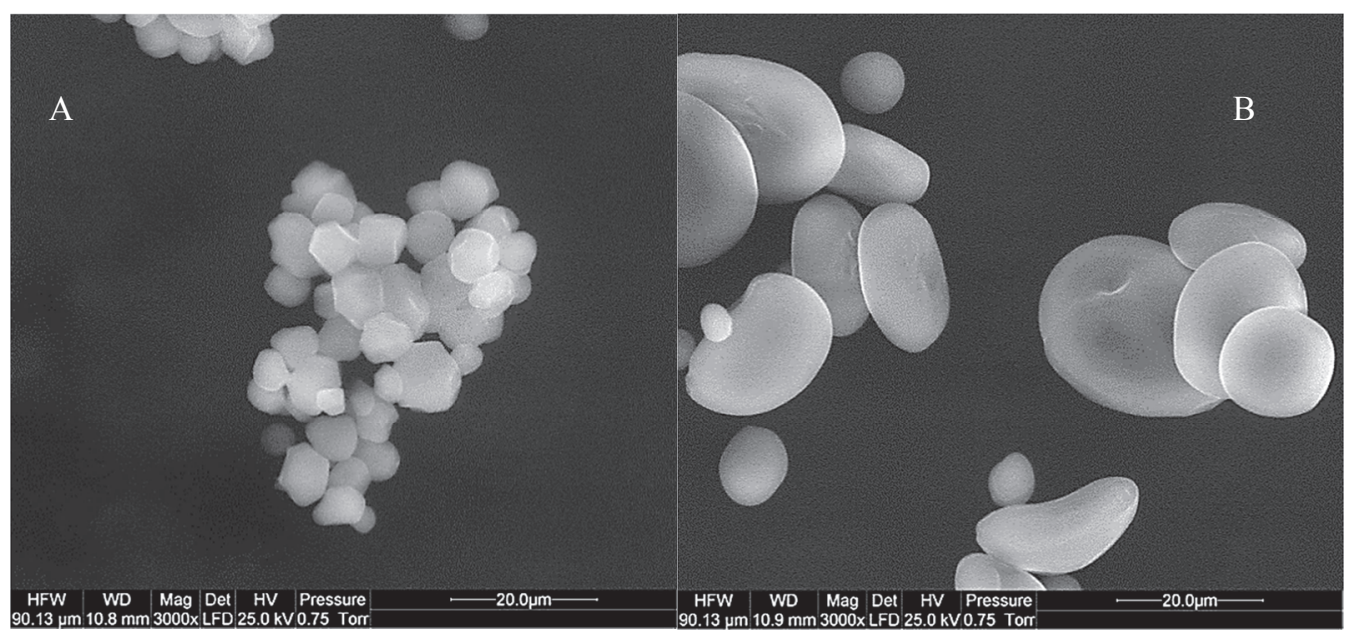

Fot. 1. Mikrofotografie SEM skrobi gryczanej (A) i skrobi pszennej (B)

Photo 1. Microphotographs (SEM) of buckwheat starch (A) and wheat starch (B)

Do badania typu krystaliczności i jej stopnia zastosowano metodę dyfrakcji promieni rentgenowskich (XRD). Analiza dyfraktogramów XRD skrobi z gryki i skrobi pszennej (rys. 1) pozwala na stwierdzenie, że obie skrobie wykazały dyfrakcję typową dla struktury polimorficznej typu A. Intensywne maksima dyfrakcyjne przy kącie odbłysku $17,0^{\circ}$ są typowe zarówno dla struktury typu B, jak i A, natomiast przy kącie odbłysku $17,9^{\circ}$ - tylko dla struktury A. Pojedynczy pik dyfrakcyjny przy kącie odbłysku $23,1^{\circ}$ zamiast dwóch pików przy kącie odbłysku $23^{\circ}$ i $24^{\circ}$ jest również typowy dla struktury A [28]. W badaniach przedstawionych w literaturze skrobia gryczana wykazywała typowe dyfraktogramy dla struktury polimorficznej typu A [7, 13].

$\mathrm{W}$ analizie mikroskopowej wykazano znaczące różnice w morfologii i wielkości ziarenek skrobi gryczanej i skrobi pszennej (fot. 1). Skrobia gryczana odznaczała się małymi ziarenkami, w większości o kształcie poligonalnym, podczas gdy wśród ziarenek skrobi pszennej o kształcie owalnym wyróżnić można było dwie populacje - ziarenek małych i dużych. Tylko pojedyncze ziarenka skrobi pszennej miały wielkość zbliżoną do ziarenek skrobi gryczanej, a większość była nawet 10 razy większa. Uzyskane wyniki obserwacji są zgodne $\mathrm{z}$ danymi zawartymi w literaturze, w których kształt skrobi gryczanej opisywany jest jako poligonalny, ale występują również ziarenka owalne i kuliste, a podawany zakres wielkości ziarenek skrobi gryczanej wynosi zazwyczaj $2 \div 10 \mu \mathrm{m}[7,13,18]$. 


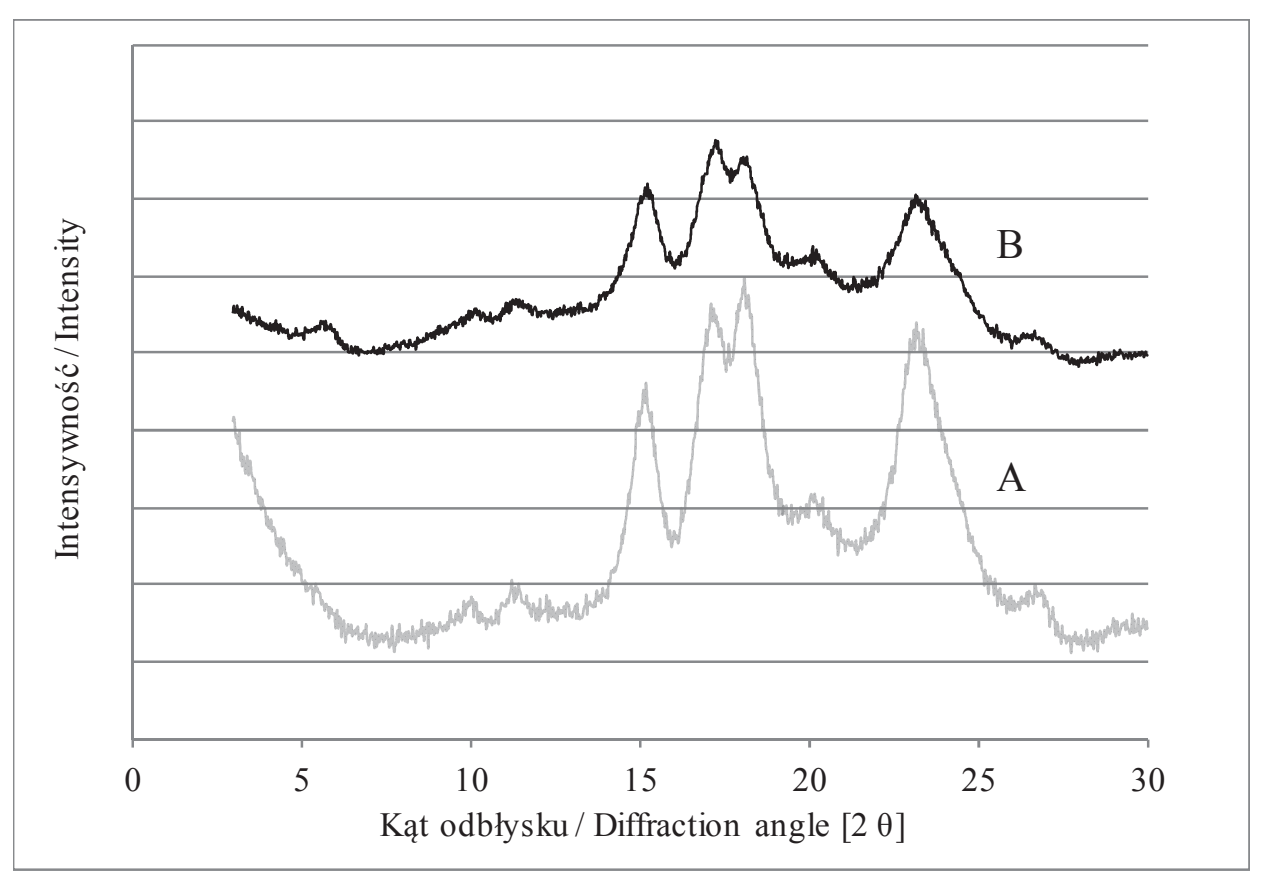

Rys. 1. Dyfraktogramy skrobi gryczanej i (A) i skrobi pszennej (B)

Fig. 1. X-ray diffraction patterns of buckwheat (A) and wheat (B) starches

Izolacja skrobi z mąki wpłynęła na właściwości termiczne skrobi, tj. zmniejszyły się temperatury przemiany, ale jej entalpia zwiększyła się (tab. 3). Należy wziąć pod uwagę, że białka tworzące otoczkę na powierzchni ziarenek skrobi znajdujących się w mące mogą utrudniać ich kleikowanie i dlatego temperatura przemiany w mące jest zazwyczaj wyższa niż w wyizolowanej skrobi [31]. Generalnie wyznaczone temperatury przemiany skrobi wyizolowanej z gryki są zgodne z danymi literaturowymi [16]. Porównując natomiast właściwości termiczne skrobi gryczanej i pszennej można zauważyć, że wielkość wszystkich parametrów wyznaczonych metodą DSC jest większa w przypadku skrobi gryczanej. Właściwości termiczne skrobi uwarunkowane są przede wszystkim wewnętrzną strukturą i wielkością jej ziarenek. O szybkości pęcznienia i kleikowania skrobi decydują m.in. oddziaływania między obszarami amorficznymi i krystalicznymi. Wartość PHI (indeks wzrostu piku) charakteryzuje kształt i stopień symetrii różnych endoterm zależnych właśnie od tego typu oddziaływań [11]. W niniejszych badaniach wielkość tego parametru wyznaczona dla obu skrobi nie różniła się istotnie. Kluczowym czynnikiem wydają się być różnice w wielkości ziarenek. Badania skrobi pszennej przeprowadzone przez Chiotelli i Le Meste [2] wykazały, że populacja małych ziarenek kleikowała w wyższej temperaturze i charakteryzowała się szerszym zakresem temperatur kleikowania niż populacja dużych ziarenek, co thuma- 
czono słabszym uporządkowaniem łańcuchów polisacharydowych w ziarenkach mniejszych w porównaniu z większymi. Wskazywać na to może również szerszy zakres temperatury kleikowania skrobi gryczanej niż skrobi pszennej (tab. 3).

Tabela 3. Właściwości termiczne mąki i skrobi gryczanej oraz skrobi pszennej

Table 3. Thermal properties of buckwheat starch and flour, and wheat starch

\begin{tabular}{|c|c|c|c||}
\hline $\begin{array}{c}\text { Parametr } \\
\text { Parameter }\end{array}$ & $\begin{array}{c}\text { Mąka gryczana } \\
\text { Buckwheat flour }\end{array}$ & $\begin{array}{c}\text { Skrobia gryczana } \\
\text { Buckwheat starch }\end{array}$ & $\begin{array}{c}\text { Skrobia pszenna } \\
\text { Wheat starch }\end{array}$ \\
\hline $\mathrm{T}_{\mathrm{o}}\left({ }^{\circ} \mathrm{C}\right)$ & $63,5^{\mathrm{c}} \pm 0,5$ & $60,3^{\mathrm{b}} \pm 0,1$ & $51,9^{\mathrm{a}} \pm 0,2$ \\
\hline $\mathrm{T}_{\mathrm{p}}\left({ }^{\circ} \mathrm{C}\right)$ & $69,7^{\mathrm{c}} \pm 0,1$ & $66,2^{\mathrm{b}} \pm 0,4$ & $56,0^{\mathrm{a}} \pm 0,2$ \\
\hline $\mathrm{T}_{\mathrm{c}}\left({ }^{\circ} \mathrm{C}\right)$ & $78,0^{\mathrm{b}} \pm 1,0$ & $78,0^{\mathrm{b}} \pm 0,7$ & $66,4^{\mathrm{a}} \pm 0,0$ \\
\hline$\Delta \mathrm{H}(\mathrm{J} / \mathrm{g})$ & $8,8^{\mathrm{a}} \pm 0,4$ & $13,9^{\mathrm{c}} \pm 0,4$ & $0,9^{\mathrm{b}} \pm 0,4$ \\
\hline $\mathrm{T}_{\mathrm{c}}-\mathrm{T}_{\mathrm{o}}\left({ }^{\circ} \mathrm{C}\right)$ & $14,6^{\mathrm{a}} \pm 1,5$ & $17,8^{\mathrm{b}} \pm 0,6$ & $14,5^{\mathrm{a}} \pm 0,2$ \\
\hline $\mathrm{PHI}$ & $1,42^{\mathrm{a}} \pm 0,03$ & $2,36^{\mathrm{b}} \pm 0,10$ & $2,64^{\mathrm{b}} \pm 0,21$ \\
\hline
\end{tabular}

Objaśnienia / Explanatory notes:

Wartości w wierszach oznaczone różnymi literami są statystycznie istotnie różne przy $p<0,05$. / Values in columns and denoted by different letters are statistically significantly different at $\mathrm{p}<0.05$. Pozostałe objaśnienia jak pod tab. 2. / Other explanatory notes as in Tab. 2.

Obserwowane różnice we właściwościach termicznych skrobi gryczanej i skrobi pszennej znalazły odzwierciedlenie w ich pęcznieniu (SP) oraz rozpuszczalności amylozy (AML) (tab. 4). Skrobia pszenna w temp. $60^{\circ} \mathrm{C}$ charakteryzowała się znacznie większą wartością SP oraz AML (odpowiednio: 9,0 g/g oraz 2,64 \%) niż skrobia gryczana, w przypadku której wartości tych parametrów wynosiły odpowiednio: 3,4 g/g i $0,32 \%$, co wynika z jej niższych temperatur kleikowania. Skrobia pszenna charakteryzowała się początkową temperaturą kleikowania zdecydowanie niższą niż skrobia gryczana. Wynosiły one odpowiednio: 51,9 i $60,3{ }^{\circ} \mathrm{C}$, dlatego w temp. $60{ }^{\circ} \mathrm{C}$ pęcznienie skrobi pszennej przebiegało szybciej. W temp. $90{ }^{\circ} \mathrm{C}$ zależność ta była odwrotna. Wartość SP skrobi gryczanej była o 60 \% większa niż skrobi pszennej, ale w przypadku AML różnice te nie były tak duże. Podobne wyniki SP w badaniach skrobi gryczanej i pszennej otrzymali Acquistucci i Fornal [1].

Liu i wsp [14] wykazali, że w wyniku zastąpienia mąki pszennej mąką gryczaną w produktach takich, jak chleb następuje zmniejszenie ich indeksu glikemicznego. Aby sprawdzić, czy wynika to ze szczególnej struktury skrobi gryczanej, czy raczej z obecności innych składników, przeprowadzono badania strawności in vitro skrobi w mące gryczanej i po wyizolowaniu, zarówno natywnych, jak i skleikowanych (tab. 5). W mące natywnej udział frakcji skrobi szybko trawionej (RDS) w skrobi ogółem wynosił tylko $10,3 \%$, natomiast $\mathrm{w}$ wyodrębnionej skrobi gryczanej frakcja ta stanowiła $55,3 \%$ i dominowała również nad skrobią pszenną (42,3 \%). 
Tabela 4. Zdolność pęcznienia i rozpuszczalność amylozy w skrobi gryczanej i pszennej

Table 4. Swelling power and amylose leaching of buckwheat and wheat starches

\begin{tabular}{|c|c|c|c|c||}
\hline $\begin{array}{c}\text { Cecha } \\
\text { Feature }\end{array}$ & $\begin{array}{c}\text { Temp. } \\
{\left[{ }^{\circ} \mathrm{C}\right]}\end{array}$ & $\begin{array}{c}\text { Mąka gryczana } \\
\text { Buckwheat flour }\end{array}$ & $\begin{array}{c}\text { Skrobia gryczana } \\
\text { Buckwheat starch }\end{array}$ & $\begin{array}{c}\text { Skrobia pszenna } \\
\text { Wheat starch }\end{array}$ \\
\hline \multirow{4}{*}{$\begin{array}{c}\text { Pęcznienie } \\
\text { Swelling power } \\
{[\mathrm{g} / \mathrm{g}]}\end{array}$} & 60 & $3,0^{\mathrm{a}} \pm 0,1$ & $3,4^{\mathrm{b}} \pm 0,1$ & $9,0^{\mathrm{c}} \pm 0,1$ \\
\cline { 2 - 5 } & 70 & $6,3^{\mathrm{a}} \pm 0,1$ & $16,6^{\mathrm{c}} \pm 0,6$ & $9,9^{\mathrm{b}} \pm 0,1$ \\
\cline { 2 - 6 } & 80 & $7,7^{\mathrm{a}} \pm 0,3$ & $16,8^{\mathrm{c}} \pm 0,8$ & $14,1^{\mathrm{b}} \pm 0,0$ \\
\cline { 2 - 6 } & 90 & $9,9^{\mathrm{a}} \pm 0,0$ & $22,8^{\mathrm{c}} \pm 0,3$ & $14,2^{\mathrm{b}} \pm 0,1$ \\
\hline \multirow{4}{*}{$\begin{array}{c}\text { Rozpuszczalność amylozy } \\
\text { Amylose leaching } \\
{[\mathrm{g} / 100 \mathrm{~g}]}\end{array}$} & 60 & $0,08^{\mathrm{a}} \pm 0,01$ & $0,32^{\mathrm{b}} \pm 0,00$ & $2,64^{\mathrm{c}} \pm 0,06$ \\
\cline { 2 - 6 } & 70 & $0,30^{\mathrm{a}} \pm 0,00$ & $4,90^{\mathrm{b}} \pm 0,40$ & $4,91^{\mathrm{b}} \pm 0,12$ \\
\cline { 2 - 6 } & 80 & $0,94^{\mathrm{a}} \pm 0,03$ & $5,11^{\mathrm{b}} \pm 0,35$ & $8,24^{\mathrm{c}} \pm 0,13$ \\
\cline { 2 - 6 } & 90 & $1,53^{\mathrm{a}} \pm 0,06$ & $9,97^{\mathrm{c}} \pm 0,27$ & $8,63^{\mathrm{b}} \pm 0,26$ \\
\hline
\end{tabular}

Objaśnienia jak pod tab. 3. / Explanatory notes as in Tab. 3.

Tabela 5. Udział skrobi: szybko trawionej (RDS), wolno trawionej (SDS) i opornej (RS) [\% skrobi całkowitej]

Table 5. Content of starches: Rapidly digestible starch (RDS), slowly digestible starch (SDS), and resistant starch (RS) [\% of total starch]

\begin{tabular}{||c|c|c|c|c||}
\hline \hline \multicolumn{2}{|c|}{ Produkt / Product } & RDS & SDS & RS \\
\hline \multirow{2}{*}{$\begin{array}{c}\text { Mąka gryczana } \\
\text { Buckwheat flour }\end{array}$} & NG & $10,3^{\mathrm{a}} \pm 0,1$ & $44,5^{\mathrm{c}} \pm 0,4$ & $45,2^{\mathrm{d}} \pm 0,3$ \\
\cline { 2 - 5 } & $\mathrm{G}$ & $85,2^{\mathrm{d}} \pm 1,8$ & $0,9^{\mathrm{a}} \pm 0,2$ & $14,0^{\mathrm{c}} \pm 1,5$ \\
\hline $\begin{array}{c}\text { Skrobia gryczana } \\
\text { Buckwheat starch }\end{array}$ & $\mathrm{NG}$ & $55,3^{\mathrm{c}} \pm 0,6$ & $44,0^{\mathrm{c}} \pm 1,0$ & $0,7^{\mathrm{a}} \pm 0,4$ \\
\cline { 2 - 5 } & $\mathrm{G}$ & $86,8^{\mathrm{d}} \pm 0,1$ & $5,7^{\mathrm{b}} \pm 0,8$ & $7,5^{\mathrm{b}} \pm 0,7$ \\
\hline $\begin{array}{c}\text { Skrobia pszenna } \\
\text { Wheat starch }\end{array}$ & $\mathrm{NG}$ & $42,3^{\mathrm{b}} \pm 1,2$ & $50,5^{\mathrm{d}} \pm 0,5$ & $7,3^{\mathrm{b}} \pm 0,8$ \\
\cline { 2 - 5 } & $\mathrm{G}$ & $92,6^{\mathrm{e}} \pm 0,1$ & $5,5^{\mathrm{b}} \pm 0,7$ & $1,9^{\mathrm{a}} \pm 0,6$ \\
\hline
\end{tabular}

Objaśnienia / Explanatory notes:

NG - niegotowana / uncooked; G - gotowana / cooked; Pozostałe objaśnienia jak pod tab. 2. / Other explanatory notes as in Tab. 2.

Udział frakcji skrobi wolno trawionej (SDS) był na tym samym poziomie w mące i w skrobi gryczanej, a w skrobi pszennej - na nieznacznie wyższym. Największe różnice stwierdzono pod względem udziału skrobi opornej, który w mące gryczanej wynosił 45,2 \%, ale po wyodrębnieniu skrobi z ziarniaków gryki znacząco zmalał $(0,7 \%)$. Jak wykazano, skrobia gryczana charakteryzuje się tym samym typem polimorficznym struktury krystalicznej jak skrobia pszenna. Tego typu struktura jest bardziej podatna na hydrolizę niż skrobia o typie polimorficznym B, charakterystycznym dla skrobi ziemniaczanej [22]. Strawność skrobi determinowana jest nie tylko strukturą krystaliczną ziarenka, ale również jego wielkością. Przeprowadzone badania kinetyki hydro- 
lizy skrobi o różnym pochodzeniu botanicznym wykazały, że stosunek powierzchni ziarenka skrobi do jego objętości jest jednym z najważniejszych wskaźników określających wielkość obszarów wiązania enzymów oraz ilość dostępnych wiązań glikozydowych [5]. Mniejsze ziarenka skrobi są trawione szybciej, dlatego większy udział skrobi gryczanej RDS niż skrobi pszennej RDS mógł być wynikiem różnic w wielkości tych ziarenek. Nie można również wykluczyć, że różnice te są efektem innego rozmieszczenia warstw krystalicznych i amorficznych w ziarenkach skrobi. Warren i wsp. [29] wykazali, że szybkość wiązania enzymów na powierzchni ziarenka skrobi jest uzależniona od udziału frakcji amorficznej w tym obszarze, tj. im większy jest jej udział tym szybsza hydroliza skrobi. Przeprowadzone badania właściwości termicznych wskazują na różnice w uporządkowaniu łańcuchów amylopektyny w skrobi pszennej i gryczanej.

Po gotowaniu wszystkich próbek udział RDS gwałtownie wzrósł do podobnego poziomu w mące i skrobi gryczanej ( $\sim 86 \%)$ i znacznie wyższego w skrobi pszennej ( 93 \%) przy jednoczesnym zmniejszeniu udziału SDS we wszystkich próbkach. Z kolei kierunek zmian udziału RS uzależniony był od rodzaju próbki - w mące gryczanej i skrobi pszennej wskutek gotowania nastąpiło zmniejszenie udziału frakcji opornej, zaś zwiększenie odnotowano w skrobi gryczanej, choć nadal jej ilość była największa w mące gryczanej.

Różnice strawności skrobi w mące gryczanej i wyodrębnionej skrobi mogą być spowodowane tym, że składniki obecne w mące gryczanej mogą wchodzić w interakcje ze skrobią lub hamować działanie enzymów amylolitycznych. Podczas ogrzewania może dochodzić np. do interakcji między białkami a skrobią, co może powodować zmniejszenie jej strawności [27]. Ponadto według Takahama i Hirota [25] rutyna i galusan epigallokatechiny, które są obecne w znacznych ilościach w gryce, wiążą się z amylozą i amylopektyną, hamując działanie pankreatyny, chociaż badania kaszy gryczanej gotowanej przed i po wyekstrahowaniu polifenoli nie wykazały istotnych różnic pod względem ilości SDS i RS [21]. Stwierdzony wysoki udział RS w mące gryczanej może też być spowodowany tym, że malutkie ziarenka skrobi znajdują się w matrycy białkowej, co, jak wynika z analiz właściwości termicznych i pęcznienia skrobi, utrudnia ich kleikowanie. Może to wpływać na obecność w mące skrobi opornej typu RS1. Wskazują na to badania kaszy gryczanej poddawanej różnym typom obróbki termicznej, po której stwierdzono różnice w udziale RS, ale ilość RS3 nie zmieniała się istotnie, więc różnice te nie były wynikiem retrogradacji skrobi [21]. Z kolei większy udział RS w skrobi gryczanej niż w pszennej może wynikać z ich różnej podatności na retrogradację. $Z$ badań przeprowadzonych przez Mikulikovą i wsp. [15] wynika, że skrobia różnych zbóż charakteryzuje się różną podatnością na retrogradację. Największy udział RS3 w skrobi po obróbce termicznej stwierdzono w ryżu, a najmniejszy - w owsie. 


\section{Wnioski}

1. Ze względu na ponad 10-krotnie mniejsze ziarenka skrobi gryczanej niż skrobi pszennej oraz prawdopodobieństwo różnic w uporządkowaniu łańcuchów polisacharydowych właściwości obu skrobi znacznie się różnią, pomimo takiego samego typu krystaliczności i podobnej zawartości amylozy. Skrobia gryczana wykazuje większą entalpię oraz temperatury przemiany niż skrobia pszenna.

2. Większe wartości temperatur kleikowania skrobi w mące gryczanej oraz niska wartość zdolności pęcznienia i rozpuszczania amylozy w porównaniu ze skrobią wyodrębnioną z mąki gryczanej wynikają prawdopodobnie z obecności białek na powierzchni ziarenek skrobi.

3. Proces izolacji skrobi z mąki gryczanej znacząco zmniejsza w niej udział frakcji skrobi opornej, który jest mniejszy niż w skrobi pszennej. Po skleikowaniu skrobi następuje zwiększenie udziału tej frakcji w skrobi gryczanej w przeciwieństwie do skrobi pszennej, co może sugerować większą podatność ziarenek tej skrobi na retrogradację.

\section{Literatura}

[1] Acquistucci R., Fornal J.: Italian buckwheat (Fagopyrum esculentum) starch: Physico-chemical and functional characterization and in vitro digestibility. Food/Nahrung, 1997, 41 (5), 281-284.

[2] Chiotelli E., Le Meste M.: Effect of small and large wheat starch granules on thermomechanical behavior of starch. Cereal Chem., 2002, 79 (2), 286-293.

[3] Christa K., Soral-Śmietana M., Lewandowicz G.: Buckwheat starch: Structure, functionality and enzyme in vitro susceptibility upon the roasting process. Int. J. Food Sci. Nutr., 2009, 60 (Supll. 4), $140-154$

[4] Chung H.J., Liu Q., Hoover R.: Impact of annealing and heat-moisture treatment on rapidly digestible, slowly digestible and resistant starch levels in native and gelatinized corn, pea and lentil starches. Carbohyd. Polym., 2009, 75, 436-447.

[5] Dhital S., Shrestha A.K., Gidley M.J.: Relationship between granule size and in vitro digestibility of maize and potato starches. Carbohydr. Polym., 2010, 82, 480-488.

[6] Englyst H.N., Kingman S.M., Cummings J.H.: Classification and measurement of nutritionally important starch fractions. Eur. J. Clin. Nutr., 1992, 46, 33-50.

[7] Gao J., Kreft I., Chao G., Wang Y., Liu X., Wang L., Wang P., Gao X., Feng B.: Tartary buckwheat (Fagopyrum tataricum Gaertn.) starch, a side product in functional food production, as a potential source of retrograded starch. Food Chem., 2016, 190, 552-558.

[8] Górecka D., Dziedzic K., Sell S.: Wpływ zabiegów technologicznych stosowanych podczas produkcji kaszy gryczanej na zawartość błonnika pokarmowego. Nauka, Przyroda, Technologie, 2010, 4 (2), 1-9.

[9] Horbowicz M., Obendorf R.L.: Changes in sterols and fatty acids of buckwheat endosperm and embryo during seed development. J. Agric. Food Chem., 1992, 40 (5), 745-750.

[10] Ikeda K., Kishida M., Kreft I., Yasumoto K.: Endogenous factors responsible for the textural characteristics of buckwheat products. J. Nutr. Sci. Vitaminol., 1997, 43 (1), 101-111.

[11] Krueger B.R., Walker C.E., Knutson C.A., Inglett G.E.: Differential scanning calorimetry of raw and annealed starch isolated from normal and mutant maize genotypes. Cereal Chem., 1987, 64, 187190.

[12] Leach H.W., Mccowen L.D., Schoch T.J.: Structure of the starch granule. I. Swelling and solubility patterns of various starches. Cereal Chem., 1959, 36, 534-537. 
[13] Liu H., Lv M., Peng Q., Shan F., Wang M.: Physicochemical and textural properties of Tartary buckwheat starch after heat - moisture treatment at different moisture levels. Starch/Stärke, 2015, 67 (3/4), 276-284.

[14] Liu W., Brennan M., Serventi L., Brennan C.: Buckwheat flour inclusion in Chinese steamed bread: Potential reduction in glycemic response and effects on dough quality. Eur. Food Res. Technol., 2017, 5 (43), 727-734.

[15] Mikulíková D., Benková M., Kraic J.: The potential of common cereals to form retrograded resistant starch. Czech J. Genet. Plant Breed., 2006, 42 (3), 95-102.

[16] Noda T., Takahata Y., Sato T., Suda I., Morishita T., Ishiguro K., Yamakawa O.: Relationships between chain length distribution of amylopectin and gelatinization properties within the same botanical origin for sweet potato and buckwheat. Carbohydr. Polym., 1998, 37 (2), 153-158.

[17] Piecyk M., Drużyńska B., Worobiej E., Wołosiak R., Ostrowska- Ligęza E.: Effect of hydrothermal treatment of runner bean (Phaseolus coccineus) seeds and starch isolation on starch digestibility. Food Res. Int., 2013, 50, 428-437.

[18] Qian J., Kuhn M.: Physical properties of buckwheat starches from various origins. Starch/Stärke, 1999, $51(2 / 3), 81-85$.

[19] Qin P., Wang Q., Shan F., Hou Z., Ren G.: Nutritional composition and flavonoids content of flour from different buckwheat cultivars. Int. J. Food Sci. Technol., 2010, 45 (5), 951-958.

[20] Skrabanja V., Laerke H.N., Kreft I.: Effects of hydrothermal processing of buckwheat (Fagopyrum esculentum Moench) groats on starch enzymatic availability in vitro and in vivo in rats. J. Cereal Sci., 1998, 28 (2), 209-214.

[21] Skrabanja V., Liljeberg Elmståhl H.G., Kreft I., Björck I.M.: Nutritional properties of starch in buckwheat products: Studies in vitro and in vivo. J. Agric. Food Chem., 2001, 49 (1), 490-496.

[22] Srichuwong S., Sunarti T.C., Mishima T., Isono N., Hisamatsu M.: Starches from different botanical sources II: Contribution of amylopectin fine structure to thermal properties and enzyme digestibility. Carbohydr. Polym., 2005, 60, 529-538.

[23] Stempińska K., Soral-Śmietana M., Zieliński H., Michalska A.: Wpływ obróbki termicznej na skład chemiczny i właściwości przeciwutleniające ziarniaków gryki. Żywność. Nauka. Technologia. Jakość., 2007, 5 (54), 66-76.

[24] Stempińska K., Soral-Śmietana M.: Składniki chemiczne i ocena fizykochemiczna ziarniaków gryki - porównanie trzech polskich odmian. Żywność. Nauka. Technologia. Jakość, 2006, 2 (47) Supl., 348-357.

[25] Takahama U., Hirota S.: Fatty acids, epicatechin-dimethylgallate, and rutin interact with buckwheat starch inhibiting its digestion by amylase: Implications for the decrease in glycemic index by buckwheat flour. J. Agric. Food Chem., 2010, 58 (23), 12431-12439.

[26] Thompson L.U., Robb P., Serraino M., Cheung F.: Mammalian lignin production from various foods. Nutr. Cancer, 1991, 16, 43-52.

[27] Thorne M.J., Thompson L.U., Jenkins D.J.: Factors affecting starch digestibility and the glycemic response with special reference to legumes. Am. J. Clin. Nutr., 1983, 38, 481-488.

[28] Wang T.L., Bogracheva T.Y., Hedley C.L.: Starch: As simple as A, B, C? J. Exp. Bot., 1998, 49, 481-502.

[29] Warren F.J., Royall P.G., Gaisford S., Butterworth P.J., Ellis P.R.: Binding interactions of $\alpha$-amylase with starch granules: The influence of supramolecular structure and surface area. Carbohydr. Polym., 2011, 86, 1038-1047.

[30] Williams P.C., Kuzina F.D., Hlynka I.: A rapid colorimetric procedure for estimating the amylose content of starches and flours. Cereal Chem., 1970, 47,411-420.

[31] Zaidul I.S.M., Absar N., Kim S.-J., Suzuki T., Karim A.A., Yamauchi H., Noda T.: DSC study of mixtures of wheat flour and potato, sweet potato, cassava, and yam starches. J. Food Eng., 2008, 86, 68-73.

[32] AOAC: Official Methods of Analysis. $15^{\text {th }}$ Ed. AOAC, Arlington, VA, USA, 1990. 


\title{
PROPERTIES AND IN VITRO DIGESTIBILITY OF BUCKWHEAT STARCH COMPARED TO WHEAT STARCH
}

\begin{abstract}
S u m m a r y
Products containing buckwheat flour are characterized by a good nutritional value and pro-health substances contained therein as well as by a low glycemic index. Those features can be useful when designing new products containing buckwheat grains. The objective of the research study was to compare some selected properties of starch isolated from buckwheat with the features of buckwheat flour and wheat starch.

It has been proved that, because the size of buckwheat starch granules is more than 10 times smaller than that of wheat starch, their properties vary widely, although the two starches have the same type of polymorphic structure and a similar content of amylose. The buckwheat starch had a higher gelatinization temperature and its enthalpy of gelatinization transition was higher than that of the wheat starch. In the case of the buckwheat flour, even higher values of gelatinization transition temperatures were recorded as were low values of swelling power and amylose leaching ability, which, likely, resulted from the presence of proteins on the surface of starch granules. Those properties affected the digestibility of starch. The starch in the buckwheat (raw) flour was characterized by a high content of resistant starch (RS); however, after it was isolated from the flour, the content of RS was insignificant and lower than that in the wheat starch. After cooking, the percentage contents of rapidly digested starch in the flour and in the isolated starch were at a similar level. After gelatinization, the content of RS was higher in the buckwheat than in the wheat starch; this fact indicated that the susceptibility of buckwheat starch to retrogradation was higher than that of the wheat starch.
\end{abstract}

Key words: buckwheat flour, buckwheat and wheat starches, resistant starch (RS), swelling power, amylose leaching 